\title{
HOW TROPICAL EPIPHYTES AT THE EDEN PROJECT CONTRIBUTE TO RAINFOREST CANOPY SCIENCE
}

\author{
Julian Donald ${ }^{1}$, Pete Maxfield, ${ }^{2}$ Don Murray ${ }^{3} \&$ M.D. Farnon Ellwood ${ }^{4}$
}

\begin{abstract}
Understanding the ecological patterns and ecosystem processes of tropical rainforest canopies is becoming increasingly urgent in the face of widespread deforestation. However, accessing rainforest canopies is far from simple, and performing manipulative experiments in the canopy is particularly challenging. Botanic gardens provide an ideal 'halfway house' between field experiments and controlled laboratory conditions. As an ideal venue for testing equipment and refining ideas, botanic gardens also provide scientists with a direct route to public engagement, and potentially to research impact. Here we describe the 'fernarium', an adjustable canopy research platform for the standardisation, manipulation and detailed study of epiphytic bird's nest ferns (Asplenium nidus) at the Eden Project in Cornwall. The fernarium provides a platform not only for the scientific study of bird's nest ferns, but for public engagement, science communication and a wider understanding of the urgent environmental issues surrounding tropical rainforests. We include some preliminary results from an experiment in which the microbial community of a fern soil at the Eden Project was found to be similar in composition to that of a fern from lowland tropical rainforest in Malaysian Borneo. This study illustrates how preliminary experiments in an indoor rainforest can inform experimental techniques and procedures fundamental to the scientific study of genuine rainforest canopies.
\end{abstract}

\section{INTRODUCTION}

\section{The challenge of rainforest canopy science}

Tropical rainforests are some of the most biodiverse yet threatened regions on the planet (Myers et al., 2000; Achard et al., 2002). Understanding the way in which rainforests function, particularly in response to environmental disturbance, is crucial (Fayle et al., 2015a). Rainforest canopies in particular are not well understood, despite being critically important in influencing the world's climate, and to global carbon and nitrogen cycles (Lowman \& Rinker, 2004). Rainforest canopies also house large numbers of 'specialists', plant and animal species adapted to specific niches, distinct from those found elsewhere in the rainforest (Nadkarni et al., 2002). Although scientific studies

1. Julian Donald is a PhD student at the University of the West of England (UWE) and is the corresponding author for this paper.

Address: UWE, Frenchay Campus, Coldharbour Lane, Bristol BS16 1QY, UK.

Email: julian.donald@uwe.ac.uk

2. Pete Maxfield is a Senior Lecturer in Environmental Biology at UWE.

Address: As above.

3. Don Murray was Head of Horticulture at the Eden Project for the duration of this study, and is now Head of Island

Landscapes and Horticulture at Mount Stuart Trust.

Address: Mount Stuart Trust, Isle of Bute, PA20 9NR, UK.

4. M.D. Farnon Ellwood is a Senior Lecturer in Environmental Biology at UWE.

Address: UWE, Frenchay Campus, Coldharbour Lane, Bristol BS16 1QY, UK. 
of these ecosystems are increasing as a result of advances in canopy access techniques (Lowman \& Schowalter, 2012), they nonetheless remain difficult environments within which to perform scientific research. The study of canopy soils in particular can be very challenging due to the sensitivity of soil microbes to environmental disturbance (Nannipieri et al., 2003; Nannipieri et al., 2012).

\section{The Eden Project}

Botanic gardens can play a key role in increasing our understanding of tropical rainforests. The global network of such institutions provides a wealth of knowledge and resources that can help scientists to understand these complex ecosystems, whilst providing a unique forum for researchers to communicate directly with the general public (Shaw, 2015).

The Eden Project in Cornwall consists of outdoor gardens and two large enclosed biomes on a 105ha site within a decommissioned china clay quarry (Fig. 1). The Rainforest Biome covers an area of $15,590 \mathrm{~m}^{2}$ and, at $50 \mathrm{~m}$ tall at its highest point, is one of the largest greenhouses in the world. Over 1,000 plant species are housed in five thematic areas (West Africa, Oceanic Islands, Amazon, Crops and Cornucopia, and Malaysia). This large-scale mixed assortment of perennial tropical plants is contained within an effectively sealed environment, under controlled levels of temperature (air $21^{\circ} \mathrm{C} \pm 3^{\circ} \mathrm{C}$, soil $20^{\circ} \mathrm{C} \pm 1^{\circ} \mathrm{C}$ ) and humidity (97 per cent \pm 3 per cent) (M. Cutler, pers. comm.). In addition to the plants introduced 15 years ago, prior to its opening, the site has been colonised by a range of local invertebrate species as well as a number of exotic introductions. These populations are closely monitored as part of a DEFRA-enforced pest management programme (Treseder et al., 2011).

The accessibility of the site for scientists and researchers, the assortment of tropical specimen plants growing under controlled conditions, and the functionally represent-

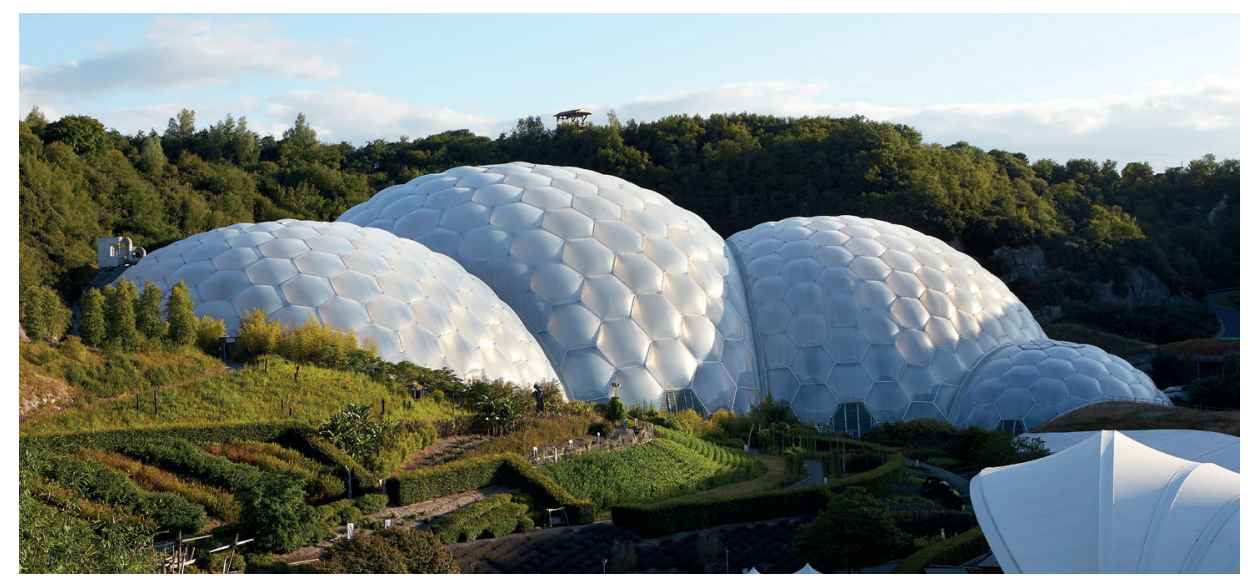

Fig. 1 The Eden Project outdoor gardens and two enclosed biomes. The Rainforest Biome is on the left. Photo: Hufton Crow. 
ative ecosystem contained within the biome all create a highly appealing opportunity for tropical ecologists to conduct tropical research from within the UK. Such experiments may be for the collection of preliminary data, or they may encompass a complete study. The on-site facilities include Industrial Rope Access Trade Association (IRATA) qualified staff, a cherry picker and a soon-to-be extended canopy walkway, making the site even more attractive to those focused on the ecology of tropical rainforest canopies (Fig. 2).

\section{EPIPHYTES AND CANOPY STUDIES}

Epiphytes are plants that are adapted to live on the trunks and branches of trees, using these larger plants as a means of support. Epiphytes are well adapted to the physically harsh, often variable conditions within the canopy (Benzing, 1983). Their ability to survive in this relatively stressful environment with minimal nutrient inputs makes them ideal specimen plants in botanic gardens. This resilience also makes them useful tools for performing ecological experiments (Srivastava et al., 2004).

The bird's nest fern (Asplenium nidus), found across much of tropical Asia and Australasia, is an epiphyte consisting of a rosette of upward-facing fronds, and a fibrous root mass, which anchors the fern to the host plant (Figs $3 \& 4$ ). The leaves trap falling litter which subsequently decomposes within the root mass, providing nutrients and moisture (Benzing, 1983; Turner et al., 2007), and a microhabitat capable of supporting

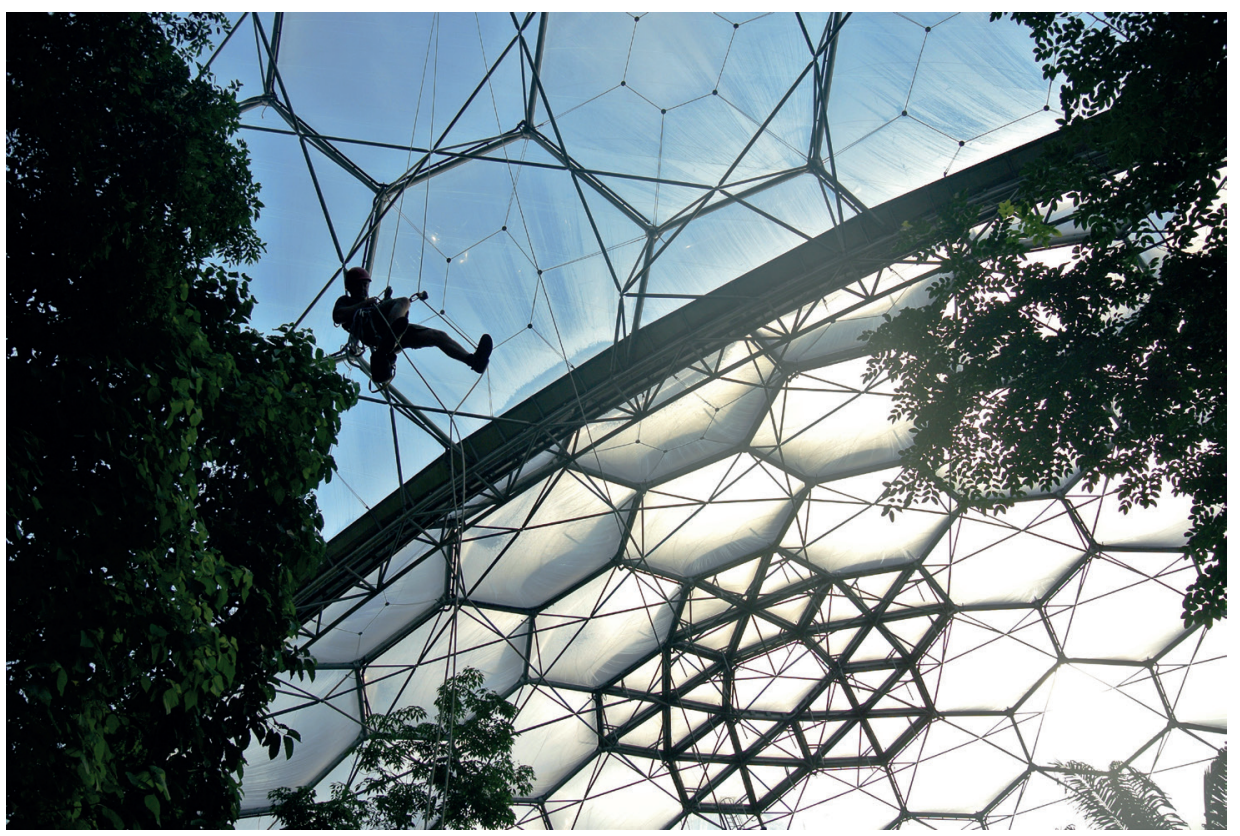

Fig. 2 Eden staff using rope access techniques within the Tropical Humid Biome. Photo: J. Donald. 


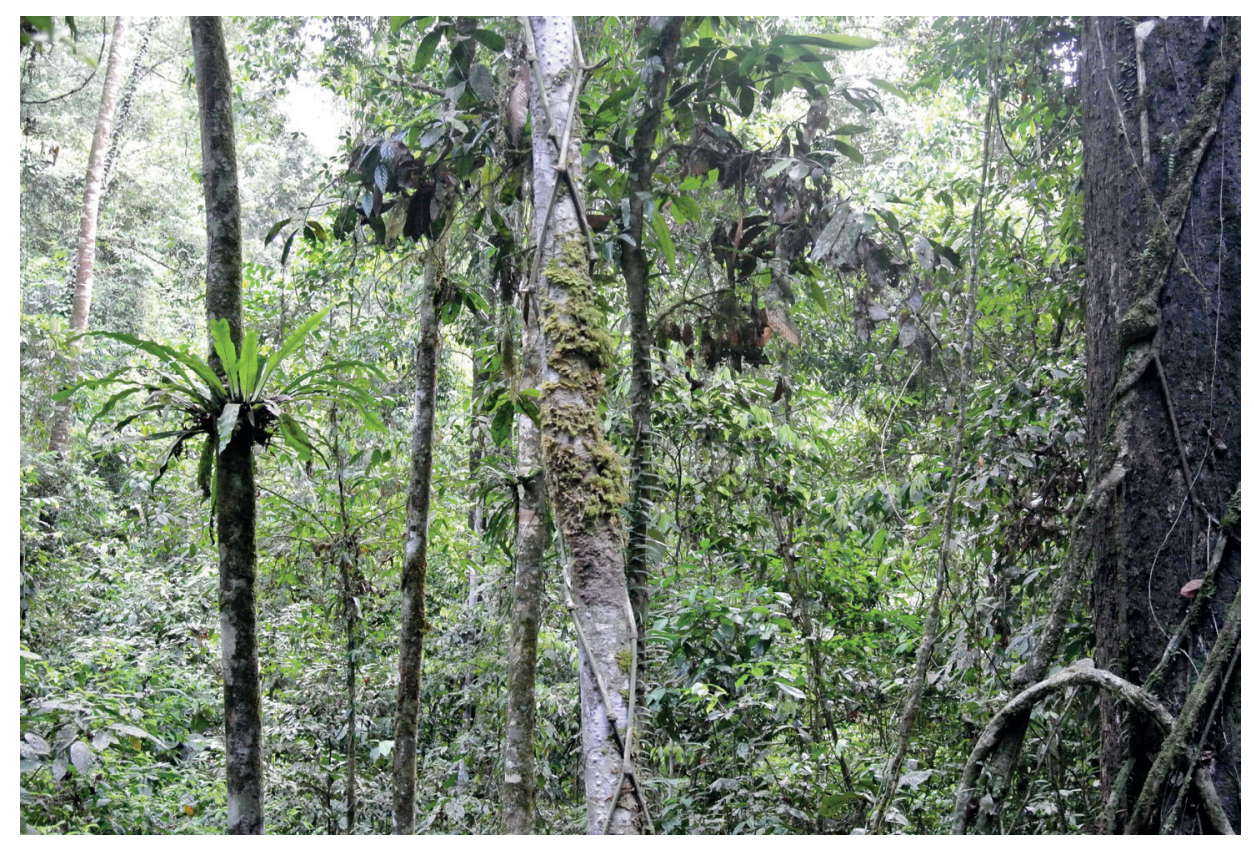

Fig. 3 An Asplenium phyllitidis fern in the lower rainforest canopy of the Danum Valley Conservation Area in Sabah, Malaysia. Photo: J. Donald.

a significant proportion of rainforest invertebrate biodiversity (Ellwood et al., 2002; Ellwood \& Foster, 2004; Dial et al., 2006). In pristine rainforest the ferns are abundant at all heights, demonstrating their ability to survive the hot and dry conditions of the canopy, as well as the more humid conditions of the understorey (Fayle et al., 2009). This tolerance for a wide range of physical conditions explains not only their prevalence in the tropical hothouses of many botanic gardens but also their popularity as ornamental plants in the landscaping of Southeast Asian cities such as Singapore.

As natural microcosms (Srivastava et al., 2004), Bird's nest ferns have been used to represent ideal natural microcosms. The ferns have been used to investigate species assembly rules among insects and other invertebrates (Ellwood et al., 2009; Fayle et al., 2015 b) and to investigate the supply of nutrients to the forest floor (Turner et al., 2007). However, little is known about the microbial community within these ferns, despite the fact that microorganisms are known to drive decomposition and nutrient cycling, thus potentially underpinning the maintenance of the high levels of species diversity within the forest canopy (Hietz et al., 2002; Cardelús, 2010).

The discrete, self-contained nature of the ferns, their resistance to desiccation and their ability to survive experimental manipulation makes this plant an ideal system, not just for studies conducted within rainforest (e.g. Ellwood et al., 2009), but for developing and testing a wide range of research questions, and for local studies in any botanic garden that includes ferns among its collection. 


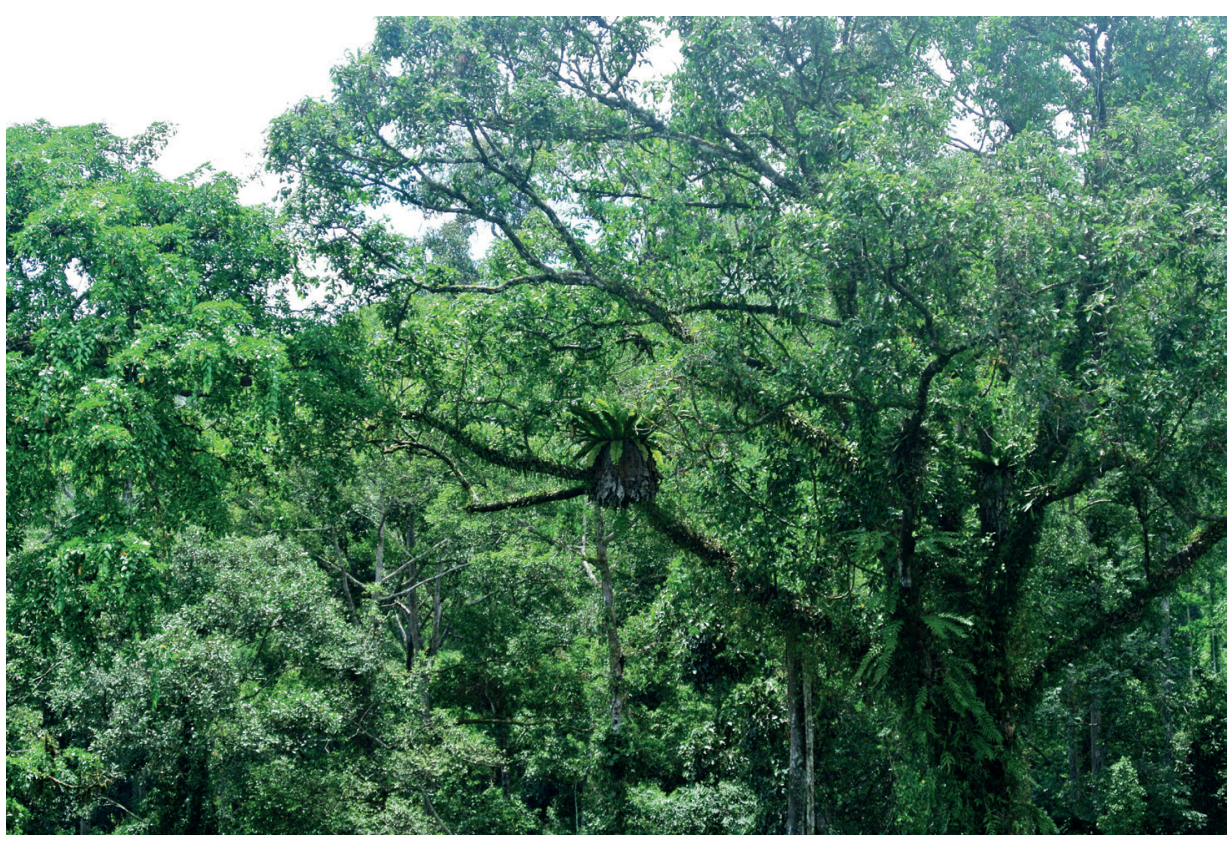

Fig. 4 A large Asplenium nidus fern approximately 50m above the ground in the Danum Valley Conservation Area in Sabah, Malaysia. Photo: J. Donald.

\section{A PLATFORM FOR CANOPY SCIENCE}

This project is a step towards understanding the functioning of epiphytic plants in threatened rainforests, taking advantage of the potential of epiphytes for microcosm studies and the convenience of a tropical botanic garden located within the UK. To make full use of these resources, it was necessary to develop an innovative canopy research platform. The resulting 'fernarium' allows the manipulation and standardisation of epiphyte microcosms whilst exploring the following key processes responsible for shaping the ecology of canopy habitats:

- nutrient inputs and rates of litter decomposition

- hydrology and nutrient leaching

- invertebrate diversity and colonisation of canopy habitats

- the role of micro-organisms in shaping canopy soils

The following describes the materials and methods used in the construction of the platform, and its placement in the canopy. A case study is presented to illustrate the utility of the fernarium as part of an experiment to characterise and compare the microbial community associated with Eden fern soil with that of a natural fern from Malaysian Borneo. 


\section{METHODS}

\section{Choosing an experimental site}

To facilitate public engagement throughout this research project, the experimental set-up was located at the centre of the Rainforest Biome. The experiments took place in two Hopea odorata trees, representatives of the Dipterocarpaceae family which dominate the forests of Southeast Asia, and which regularly host bird's nest ferns (Ellwood et al., 2002; Ellwood \& Foster, 2004). The original tree germplasm was collected in 1998 from Danum Valley Field Centre - which is also the location of our accompanying experimental fieldwork - and the Innoprise-FACE Foundation Rainforest Rehabilitation Project (INFAPRO). Germplasm was transported to Eden's Watering Lane Nursery for germination and early growth, ready for direct planting during construction in 2000-2001. When planted, the trees were approximately $1 \mathrm{~m}$ in height, but after 15 years they have grown to around 25m (Fig. 5).

The experiment required 20 bird's nest ferns, which were procured from Western Wholesale Plants Nursery in Chippenham, and, after spending three months in quarantine at the Watering Lane Nursery, were introduced to the biome. The ferns were transferred into aquatic plant pots $17 \mathrm{~cm}$ in diameter. Unlike conventional plant pots, the aquatic pots maintained the through-flow of water and the exposure of the root ball to air as experienced by natural ferns, whilst holding the root and soil material in position.

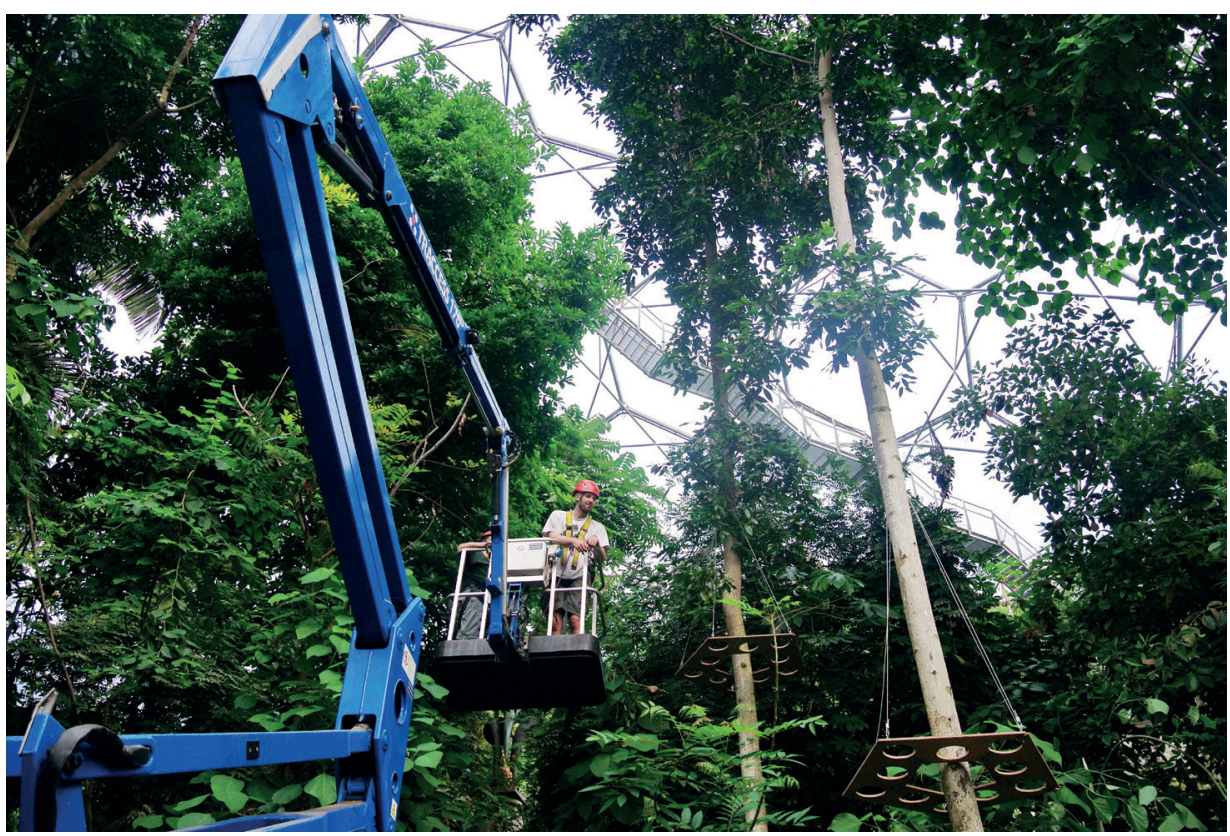

Fig. 5 Installing the fernarium using a cherry picker. The platforms are suspended around two Hopea odorata trees using galvanised steel wire attached to the roof. Photo: J. Donald. 


\section{The fernarium}

This study attempts to reproduce similar conditions to those experienced by bird's nest ferns in natural forests, i.e. exposure to direct sunlight, height in the canopy and leaf litter inputs. It was also important to be able to manipulate and standardise conditions such as temperature, humidity and rainfall, to ensure that the surrounding physical conditions were as authentic as possible. These experimental criteria were satisfied by the development of a canopy research platform known as a fernarium. Moreover, given the location of our experiments in the centre of the biome, the experiment was shared in real time with the general public.

Two platforms with a diameter of $1 \mathrm{~m}$ were constructed using marine plywood, stainless steel plates, bolts and galvanised steel wires. The platforms were assembled around the trunks of the two $H$. odorata trees. Designed to hold ten A. nidus ferns closely encircling the trunks, the platform allowed ferns to intercept the leaf litter of their host trees as they would under natural forest conditions (Figs $6 \& 7$ ). The weight of the platforms was supported by a galvanised steel cable attached to the roof of the Rainforest Biome. Although the anchor point on the roof was fixed, the attachments to the platforms were adjustable, meaning that the platform could slide up and down the tree trunks, and be positioned at any height.

Each platform was equipped with an irrigation system connected to the biome's rainwater-fed reservoir (Fig. 8). To monitor the presence of invertebrates in and around

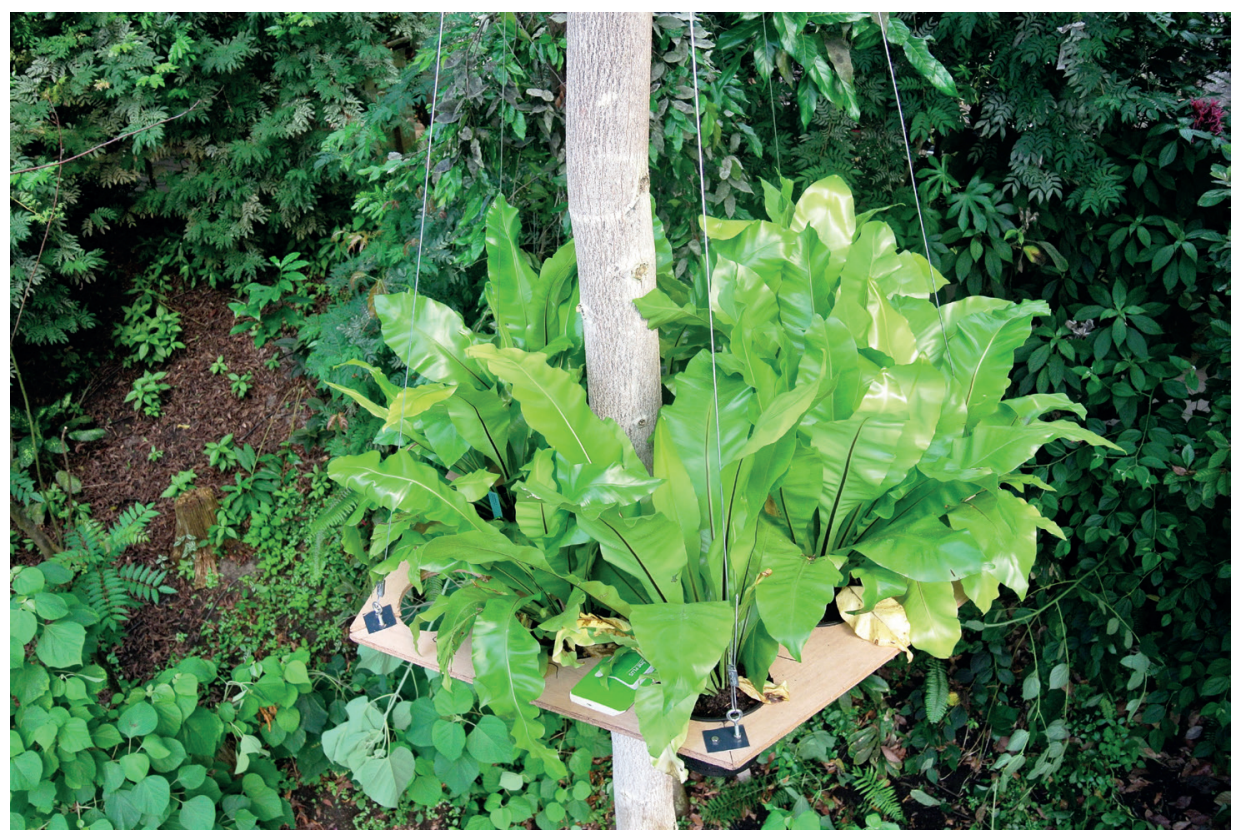

Fig. 6 Ten Asplenium nidus ferns positioned within the fernarium, with a green Agrisense sticky trap shown. Photo: J. Donald. 


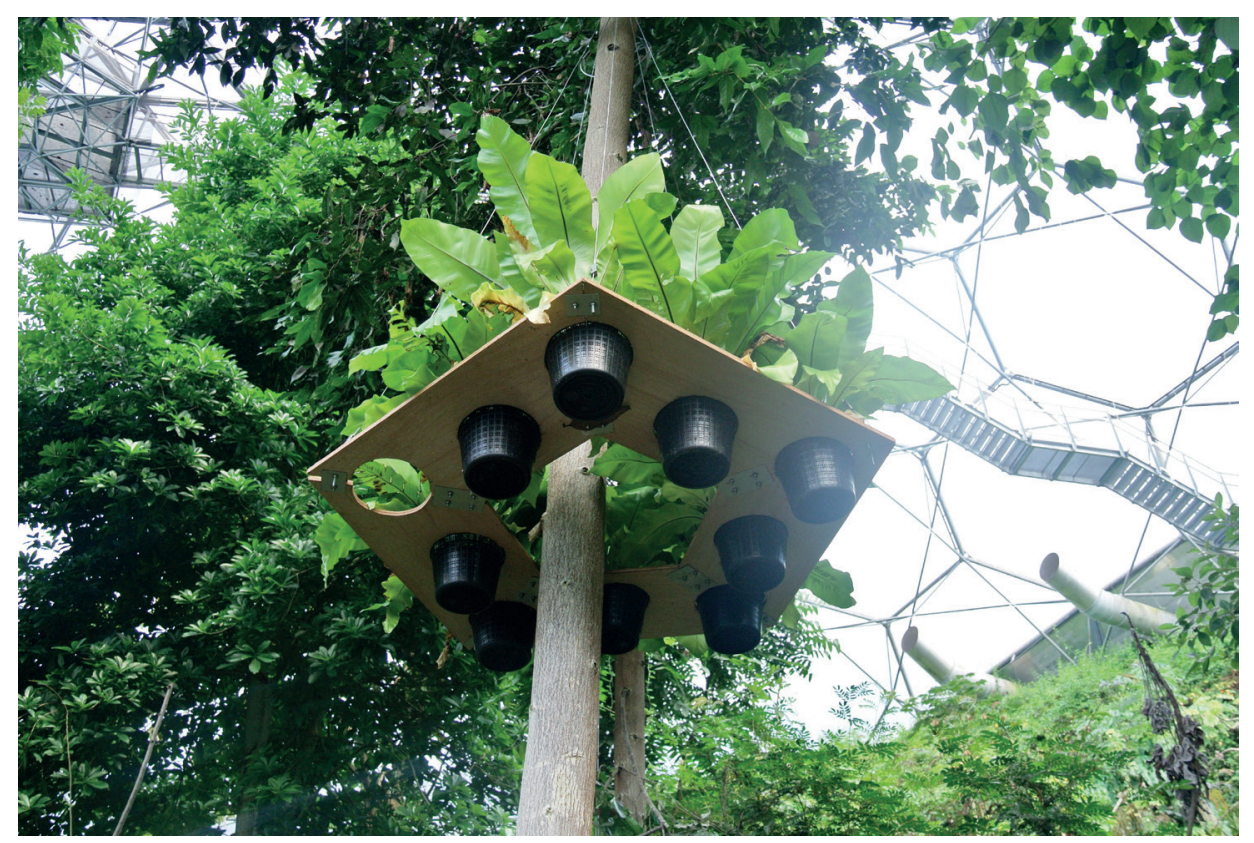

Fig. 7 Aquatic plant pots holding the fern roots and soil in place whilst allowing water through-flow that reflects natural plant conditions. Photo: J. Donald.

the ferns, three Agrisense pre-baited cockroach traps from Killgerm were attached at equidistant positions on each platform (Fig. 6). These were collected after one month, time enough to give a good insight into the movements of insects in and around the ferns. The tapered shape of the pots held each of the ten ferns in position without the need to fix them to the platform, hence the soil contained within these pots was easily sampled.

\section{Soil microbial community}

The standardised replicated conditions of the fernarium facilitated experiments to explore the microbial community associated with bird's nest ferns. Phospholipid Fatty Acid (PLFA) analysis was used to compare the community composition of a fern placed in the fernarium at the Eden Project with a natural fern collected from the Danum Valley Conservation Area in Sabah, Malaysian Borneo. The cell wall of micro-organisms is made up of PLFAs, with discrete groups of micro-organisms possessing different PLFAs within their cell walls. These components can be used as biomarkers to indicate the abundance and composition of the different constituents of the microbial community (Frostegård et al., 2011).

A sample of soil was collected from the base of each fern and freeze dried. PLFAs were extracted using the methodology outlined in Dickson et al. (2009). The extract 


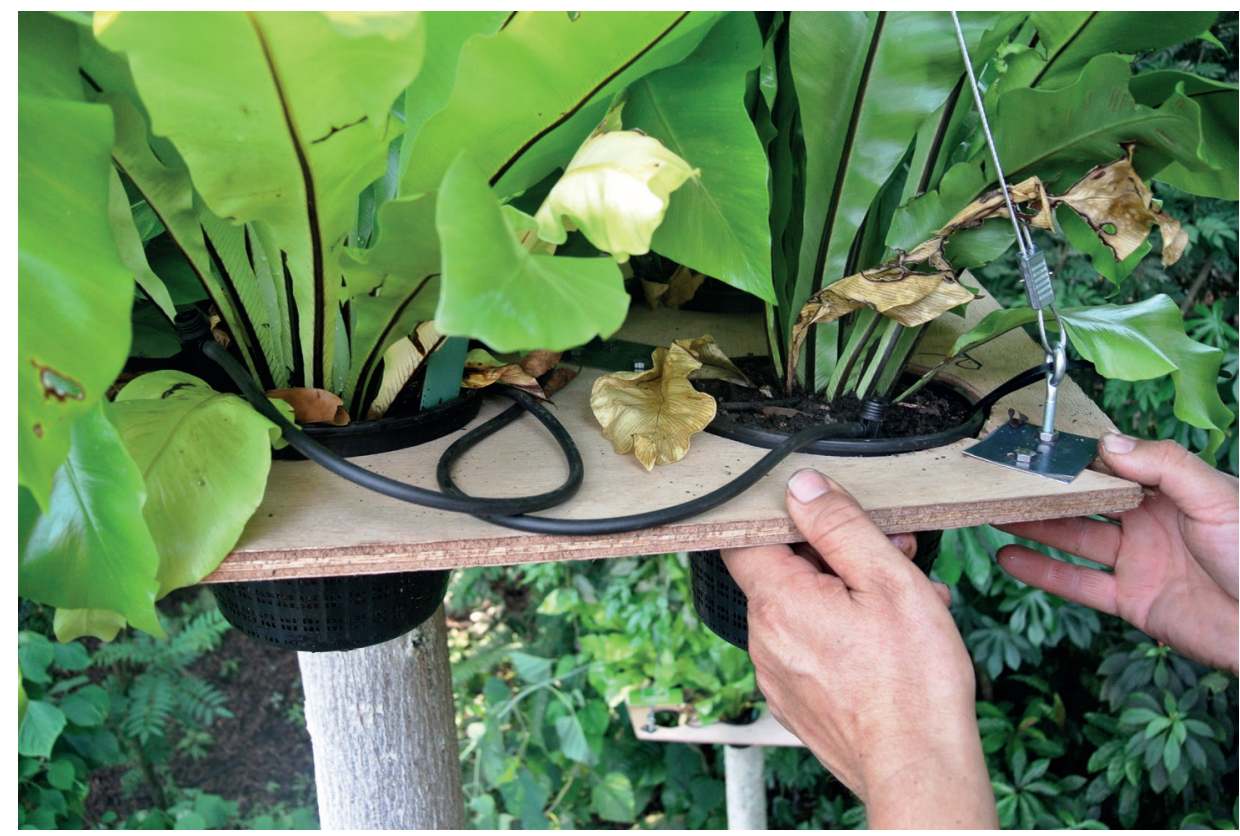

Fig. 8 Irrigation system which can be customised to deliver varying amounts of water and nutrients to simulate projected climate change scenarios. Photo: J. Donald.

was analysed using gas chromatography-mass spectrometry (GC-MS). The peaks displayed on the resulting chromatogram were identified as either bacterial or fungal as specified by Frostegård \& Bååth (1996) and fungal:bacterial ratios were calculated for each fern.

\section{RESULTS \& DISCUSSION}

\section{Science communication}

With attractive, enticing and often unique collections, botanic gardens can play a key role in both biological research and public engagement. Disseminating scientific research to the general public can prove challenging for academics, in spite of the inherent value of communicating with a wider audience. Public engagement and scientific impact is becoming increasingly important, with government funding now contingent upon research achieving impact as measured, for example, via the UK government's Research Excellence Framework (REF). The Eden Project can receive as many as 13,000 visitors per day, and from their central positon in the biome, the fernarium experiments are seen by large numbers of people. In addition to its central location, the fernarium captures the attention of the public owing to its size, its unusual shape in the form of a pentagon and the fact that it is raised above the ground. By providing an adjacent information 
board, written in lay language, members of the public are able to satisfy their curiosity by reading about the experimental set-up and the aims of the research, regardless of prior scientific education. Talks were given throughout the experiments to members of the public and to staff; this provided an opportunity not only for public engagement but for knowledge exchange with the Eden science team and garden staff.

\section{Contributions to canopy science}

By developing a platform that can support epiphytes under standardised conditions, similar to those found in the Malaysian rainforest from which the Eden plants were originally sourced, the fernarium allows canopy scientists to conduct preliminary research before embarking on overseas fieldwork. For example, suspended soils within the canopy have been described as integral components of ecosystem-level nutrient cycles (Cardelús, 2010). Thanks to its position immediately below the crown of a rainforest tree species, the platform can be used to study leaf litter inputs as a source of nutrients for canopy epiphytes, and as an ecosystem model for the process of decomposition.

The nutrients associated with suspended soils are released through leaching (Umana \& Wanek, 2010; Turner et al., 2007; Zimmermann et al., 2007), and thus the water inputs associated with these plants will determine not only plant survival but also nutrient retention. Building a remotely controlled irrigation system into the fernarium allowed the experimental modification of the water supply to the ferns and thus made it possible to investigate the impacts of drought or heavy rainfall on leaching and nutrient cycling, as well as biological processes within ferns. Levels of irrigation can simulate precipitation rates in line with climate change projections (Sheffield \& Wood, 2008). Thus it is possible to evaluate the effects of changing rainfall patterns, not only on the health of the plants themselves, but also on the functioning of their associated suspended soils. Using the same system, levels of nutrients provided to the plants can be manipulated in an attempt to understand the impacts of human-driven nutrient deposition on rainforests (Hietz et al., 2002; Hietz et al., 2011).

Given their role in sequestering organic matter, nutrients and water, canopy epiphytes such as the bird's nest fern represent a significant resource for canopy organisms, particularly arthropods (Ellwood et al., 2002; Ellwood \& Foster, 2004). The species richness and sheer abundance of invertebrates in tropical habitats can make experimental manipulations of complex ecological interactions especially difficult. However, the simplified, standardised conditions associated with botanic gardens mean that, although invertebrate diversity is orders of magnitude lower, and in some cases precisely because of this, it is still possible to complete worthwhile ecological experiments. For example, sticky traps revealed that standardised ferns situated in the Eden Project were rapidly colonised by a sufficient yet experimentally tractable diversity of white-footed ants (Technomyrmex albipes), Surinam cockroaches (Pycnoscelus surinamensis) and Australian cockroaches (Periplaneta australasiae). From a practical perspective, this discovery suggests that invertebrates such as cockroaches are using pockets of organic matter and suspended 
soils within epiphytes as they would in the rainforest canopy, and are perhaps escaping conventional pest control methods.

\section{Soil microbial community}

Microbes inhabiting suspended soils such as those found around bird's nest ferns are likely to play a key role in organic matter decomposition, nutrient cycling and the viability of the fern (Cardelús, 2010). By recreating near-natural conditions of epiphytic ferns and their suspended soil under standardised conditions, the fernarium facilitates the research and development of methods for sampling and understanding soil microbe communities. The mobile plant pots can be removed from the platform, allowing for the rapid and non-invasive collection of soil samples. Moreover, given the sensitivity of soil analysis techniques to disturbance and environmental fluctuations, it is enormously beneficial to be able to standardise temperature and humidity, perform experiments in a secure location such as the Rainforest Biome, and take advantage of the site's proximity to universities and laboratory facilities. The diverse yet controlled nature of the biome's ecosystem also strengthens its use as a site for exploring ecosystem function, in comparison to the more sterile conditions of classic greenhouse studies.

A range of PLFAs were extracted and identified from the fern soil contained within the Rainforest Biome at the Eden Project (Fig. 9). These can be used to reveal the constituent

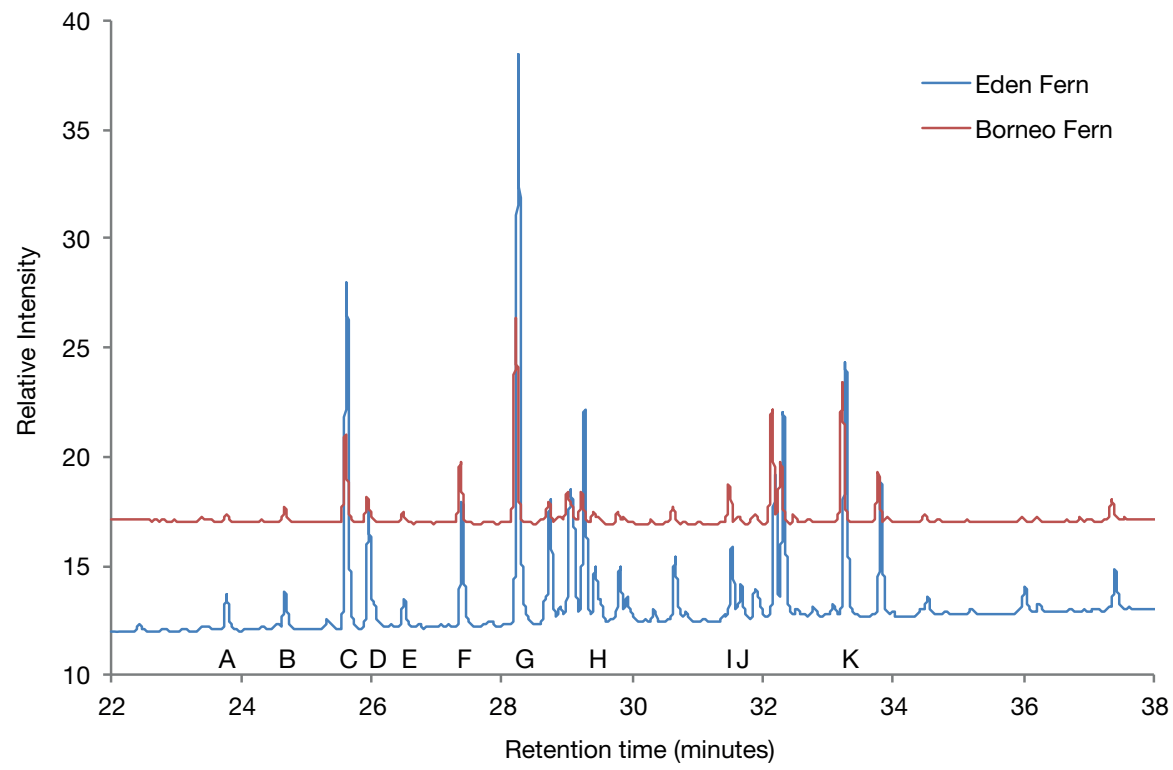

Fig. 9 Chromatogram displaying the PLFA profiles of a soil collected from a bird's nest fern at the Eden Project Cornwall, and from the Danum Valley Conservation Area in Sabah, Malaysian Borneo. Peaks indicate the relative abundance of phospholipids within each sample. By comparing peak areas against others on the same trace, it is possible to evaluate the composition of the microbial community of each sample. Peaks A-J are biomarkers of bacteria whilst peak K is indicative of fungi (as identified by Frostgård \& Baath, 1996). 
parts of the microbial community, and their relative importance in comparison with ferns from natural forests. Eden fern soil contains a microbial community with a fungal:bacterial ratio of 0.02:0.98, whilst fern soil from the Danum Valley in Malaysian Borneo displays a fungal:bacterial ratio of $0.23: 0.77$. This result suggests that fungi are of greater importance in the fern's natural habitat, probably due to the prevalence of a more developed fungal community in the surrounding rainforest canopy compared with the Eden biome. In spite of the difference in composition, the range of PLFAs appears consistent with those found in a fern from Borneo. Peaks indicating the phospholipids $i 15: 0,16: 0$ and 18:1@2 dominate both traces (labelled C, G and $\mathrm{K}$ in Fig. 9), which indicates that similar key microbial groups predominate in both systems. By enabling the quantification of fungal:bacteria ratios and the determination of community composition, this study demonstrates the feasibility of using Eden ferns to conduct research on a genuine rainforest system.

\section{CONCLUSION}

Botanic gardens can be used by scientists to perform experiments while maximising public engagement and generating impact from their work. Moreover, the results can be used to inform the future management of the gardens, generating valuable knowledge exchange between scientists and horticulturists. The fernarium will continue to facilitate canopy research at the Eden Project, allowing scientists to explore the key biotic and abiotic processes shaping canopy ecosystems, whilst enabling the perfection of experiments that may be difficult to develop under field conditions.

\section{ACKNOWLEDGEMENTS}

We are grateful for the enthusiastic support of the Eden Project Horticulture Team, particularly Hetty Ninnis, Dina Gallick, Lucie Oldale, Craig Lewis and Lucy Wenger for help in installing the ferns and for monitoring them continuously. We thank James Wagstaffe and the Eden Nursery team for their care of the ferns prior to experimental use. We are grateful to Jamie Robson and Luke Fox for their rope access work and platform suspension. Michael Cutler designed and installed the fern irrigation system and Marc Mappley supplied the insect traps. Rachel Warmington and Katie Treseder provided logistical assistance. We thank Josie Phillips for helpful comments on the manuscript.

\section{REFERENCES:}

ACHARD, F., EVA, H.D., STIBIG, H.J., MAYAUX, P., GALLEGO, J., RICHARDS, T. \& MALINGREAU, J.P. (2002). Determination of deforestation rates of the world's humid tropical forests. Science, 297(5583), 999-1002.

BENZING, D.H. (1983). Vascular epiphytes: A survey with special reference to their interactions with other organisms. In: SUTTON, S.L., WHITOMORE, T.C. \& CHADWICK, A.C. (eds). 
Tropical Rainforest: Ecology and Management. Blackwell Scientific Publications, Oxford, pp. 11-24.

CARDELÚS, C.L. (2010). Litter decomposition within the canopy and forest floor of three tree species in a tropical lowland rain forest, Costa Rica. Biotropica, 42(3), 300-308.

DIAL, R.J., ELLWOOD, M.D.F., TURNER, E.C. \& FOSTER, W.A. (2006). Arthropod abundance, canopy structure, and microclimate in a Bornean lowland tropical rain forest. Biotropica, 38(5), 643-652.

DICKSON, L., BULL, I.D., GATES, P.J. \& EVERSHED, R.P. (2009). A simple modification of a silicic acid lipid fractionation protocol to eliminate free fatty acids from glycolipid and phospholipid fractions. Journal of Microbiological Methods, 78(3), 249-254.

ELLWOOD, M.D.F. \& FOSTER, W.A. (2004). Doubling the estimate of invertebrate biomass in a rainforest canopy. Nature, 429(6991), 549-551.

ELLWOOD, M.D.F., JONES, D.T. \& FOSTER, W.A. (2002). Canopy ferns in lowland dipterocarp forest support a prolific abundance of ants, termites, and other invertebrates. Biotropica, 34(4), 575-583.

ELLWOOD, M.D.F., MANICA, A. \& FOSTER, W.A. (2009). Stochastic and deterministic processes jointly structure tropical arthropod communities. Ecology Letters, 12(4), 277284.

FAYLE, T.M., CHUNG, A.Y.C., DUMBRELL, A.J., EGGLETON, P. \& FOSTER, W.A. (2009). The effect of rain forest canopy architecture on the distribution of epiphytic ferns. Biotropica, 41(6), 676.

FAYLE, T.M., TURNER, E.C., BASSET, Y., EWERS, R.M., REYNOLDS, G. \& NOVOTNY, V. (2015a). Whole-ecosystem experimental manipulations of tropical forests. Trends in Ecology \& Evolution, 30(6), 334-346.

FAYLE, T.M., EGGLETON, P., MANICA, A., YUSAH, K.M. \& FOSTER, W.A. (2015b). Experimentally testing and assessing the predictive power of species assembly rules for tropical canopy ants. Ecology Letters, 18(3), 254-262.

FROSTEGÅRD, Å \& BÅÅTH, E. (1996). The use of phospholipid fatty acid analysis to estimate bacterial and fungal biomass in soil. Biology and Fertility of Soils, 22(1-2), 59-65.

FROSTEGÅRD, Å, TUNLID, A. \& BÅÅTH, E. (2011). Use and misuse of PLFA measurements in soils. Soil Biology and Biochemistry, 43(8), 1621-1625.

HIETZ, P., TURNER, B.L., WANEK, W., RICHTER, A., NOCK, C.A. \& WRIGHT, S.J. (2011). Long-term change in the nitrogen cycle of tropical forests. Science, 334(6056), 664-666.

HIETZ, P., WANEK, W., WANIA, R. \& NADKARNI, N.M. (2002). Nitrogen-15 natural abundance in a montane cloud forest canopy as an indicator of nitrogen cycling and epiphyte nutrition. Oecologia, 131(3), 350-355.

LAMBAIS, M.R., LUCHETA, A.R. \& CROWLEY, D.E. (2014). Bacterial community assemblages associated with the phyllosphere, dermosphere, and rhizosphere of tree species of the Atlantic forest are host taxon dependent. Microbial Ecology, 68 (3), 567-574.

LOWMAN, M.D. \& RINKLER, H.B. (2004). Forest Canopies. Academic Press, San Diego.

LOWMAN, M.D. \& SCHOWALTER, T.D. (2012). Plant science in forest canopies - the first 30 years of advances and challenges (1980-2010). New Phytologist, 194(1), 12-27. 
MYERS, N., MITTERMEIER, R.A., MITTERMEIER, C.G., DA FONSECA, G.A. \& KENT, J. (2000). Biodiversity hotspots for conservation priorities. Nature, 403(6772), 853-858.

NADKARNI, N.M., SCHAEFER, D., MATELSON, T.J. \& SOLANO, R. (2002). Comparison of arboreal and terrestrial soil characteristics in a lower montane forest, Monteverde, Costa Rica. Pedobiologia - International Journal of Soil Biology, 46(1), 24-33.

NANNIPIERI, P., ASCHER, J., CECCHERINI, M., LANDI, L., PIETRAMELLARA, G. \& RENELLA, G. (2003). Microbial diversity and soil functions. European Journal of Soil Science, 54(4), 655-670.

NANNIPIERI, P., GIAGNONI, L., RENELLA, G., PUGLISI, E., CECCANTI, B., MASCIANDARO, G., FORNASIER, F., MOSCATELLI, M.C. \& MARINARI, S. (2012). Soil enzymology: classical and molecular approaches. Biology and Fertility of Soils, 48(7), $743-762$.

SHAW, K. (2015). Encouraging and enabling science-based approach to ecological restoration: an introduction to the work of the Ecological Restoration Alliance of Botanic Gardens (ERA). Sibbaldia, 13, 145-152.

SHEFFIELD, J. \& WOOD, E.F. (2008). Projected changes in drought occurrence under future global warming from multi-model, multi-scenario, IPCC AR4 simulations. Climate Dynamics, 31(1), 79-105.

SRIVASTAVA, D.S., KOLASA, J., BENGTSSON, J., GONZALEZ, A., LAWLER, S.P., MILLER, T.E., MUNGUIA, P., ROMANUK, T., SCHNEIDER, D.C. \& TRZCINSKI, M.K. (2004). Are natural microcosms useful model systems for ecology? Trends in Ecology \& Evolution, 19(7), 379-384.

TRESEDER, K., PYTEL, M., MAPPLEY, M., GRIFFITHS, A. \& PETTITT, T. (2011). Evolution of pest management strategies in the Rain-forest Biome at the Eden Project, the first 10 years. Outlooks on Pest Management, 22(1), 22-31.

TURNER, E.C., SNADDON, J.L., JOHNSON, H.R. \& FOSTER, W.A. (2007). The impact of bird's nest ferns on stemflow nutrient concentration in a primary rain forest, Sabah, Malaysia. Journal of Tropical Ecology, 23(6), 721-724.

UMANA, N.H. \& WANEK, W. (2010). Large canopy exchange fluxes of inorganic and organic nitrogen and preferential retention of nitrogen by epiphytes in a tropical lowland rainforest. Ecosystems, 13(3), 367-381.

ZIMMERMANN, A., WILCKE, W. \& ELSENBEER, H. (2007). Spatial and temporal patterns of throughfall quantity and quality in a tropical montane forest in Ecuador. Journal of Hydrology, 343(1), 80-96. 